\title{
'Behavioural System Dynamics': a very tentative and slightly sceptical map of the territory
}

Article

Accepted Version

Lane, D. C. (2017) 'Behavioural System Dynamics': a very tentative and slightly sceptical map of the territory. Systems Research and Behavioral Science, 34 (4). pp. 414-423. ISSN 1099-1743 doi: https://doi.org/10.1002/sres.2465 Available at https://centaur.reading.ac.uk/70529/

It is advisable to refer to the publisher's version if you intend to cite from the work. See Guidance on citing.

To link to this article DOI: http://dx.doi.org/10.1002/sres.2465

Publisher: John Wiley \& Sons, Ltd

All outputs in CentAUR are protected by Intellectual Property Rights law, including copyright law. Copyright and IPR is retained by the creators or other copyright holders. Terms and conditions for use of this material are defined in the End User Agreement.

www.reading.ac.uk/centaur

\section{CentAUR}


Central Archive at the University of Reading

Reading's research outputs online 


\section{'Behavioural System Dynamics': A very tentative and slightly sceptical map of the territory}

David C Lane

Correspondence to: Prof David C Lane, Henley Business School, Whiteknights, Reading, RG6 6UD, England.

E-mail: d.c.lane@henley.ac.uk

\section{Repository Note}

This document is the accepted version of the following article:

Lane DC. 2017. 'Behavioural System Dynamics': A very tentative and slightly sceptical map of the territory Systems Research and Behavioral Science 34(4): 414-423.

The paper is posted via:

http://onlinelibrary.wiley.com/doi/10.1002/sres.2465/full

Note that the published version may have some differences from the version here. In all cases, the published version takes precedence.

If you wish to cite the ideas in this paper then please cite the version published in $S R \& B S$, NOT this version.

Please contact the Corresponding Author if you have any queries. 


\title{
'Behavioural System Dynamics': A very tentative and slightly sceptical map of the territory
}

\author{
David C. Lane ${ }^{1}$
}

Henley Business School, England

\author{
Galileo: Look, Sagredo, I believe in Humanity, which means to say I believe in \\ human reason ... \\ Sagredo: Then let me tell you something. I don't.
}

Life of Galileo, Brecht (2006, p. 29)

\section{Introduction}

In this piece I consider the paper by Stouten et al. (2017b) in terms of Behavioural Science. I first consider what, in broad terms, a 'behavioural turn' might offer System Dynamics (SD) and then explore in more detail the scope of the territory within which a behavioural approach to SD might be useful.

The field of SD does not lack interesting and important research questions. Some of these concern technical aspects of modelling: how can a complex model be calibrated? How can the subtle shifts in loop dominance best be understood? These (and other) significant areas undoubtedly merit the attention they are receiving (e.g. see Rahmandad, et al., 2015). However, stepping back for a moment, work in this area can be seen as part of SD's over-arching aspiration: to understand the counter-intuitive behaviour of social systems in order to formulate policies which improve their behaviour. In their insightful treatment of tests for building confidence in SD models Forrester and Senge (1980) offer a layered set of tests, tests ranging from the qualitative to the quantitative, tests which are best done at different points in any modelling study, tests which require iterations and revisitation. Strikingly, they suggest that the "ultimate" test of a model is the "System Improvement Test', which "considers whether or not policies found beneficial after working with a model, when implemented, also improve real-system behavior" (ibid., both p. 224). This pinnacle of their schema reveals the critical need to make actual human beings do something different as a result of their engagement with an SD model. It is a bold insight but needs to be understood not as a rejection of the technical aspects of model. The point is well put by; "The technocratic view is faulty, not because it is incorrect, but because it is incomplete." (Tinker \& Lowe, 1984, p. 45). If we accept this broadening of our view then the range of research areas for SD expands greatly - and into distinctly non-technical areas. Those areas are described variously as concerning human behaviour, social aspects, organization and individual cultures, subjectivity, etc. etc. The term 'socio-technical' is used to describe an understanding of the need to take this broad view (Trist \& Bamforth, 1951; Emery \& Trist, 1969). Yet another version of this broad idea is that people do not always do what they 'ought', what rationality suggests they should do.

\footnotetext{
${ }^{1}$ Correspondence to: Prof David C Lane, Henley Business School, Whiteknights, Reading, RG6 6UD, England.E-mail: d.c.lane@henley.ac.uk
} 
In fact, an interest in the need to engage with the subjectivity, the reality, the curiousities of how humans actually behave is seen throughout the SD literature. It is found in other tests within Forrester and Senge's (1980) schema (e.g. 'face validity'). It can be seen in Forrester's earliest ideas of how modelling must be done in very close association with policy makers (Forrester, 1961), and how it is the process of building and using a model which is likely to be at least as significant as the simulation/mathematical artefact that we think of as 'the model' - these being, arguably, amongst the defining features of the field (Lane, 2010). More recently these ideas have been related to ideas in system science and operational research regarding social theory (modelling provides a process for negotiating inter-subjective meaning within a group, e.g. Checkland, 1981; Lane, 1999b ) and group problem solving (modelling provides a means of creating a shared description of reality and catalysing commitment to action e.g. Phillips, 1984; Eden, 1992; Lane, 1992; Vennix, 1996). Robing these ideas in the fine garments of deep theory can be helpful (Lane, 2006) but these lessons are also known to modelling practitioners whose 'experience in the field' has made them all too aware of the need to deal with the vagaries and capriciousness of actual human being if they truly wish to effect organisational change (Gass, 1983; Senge, 1990; Miser, 2001; Weil, 2007; Roberts, 2007). The insights manifest in various ways:

"We still imagine that an optimal solution will be executed by the empowered parties simply because it shines with self-evident truth. The reality is that any problem is embedded in a network of political, cultural and power relationships." (Lane, 1992, p. 67)

Or, laconically; "People matter." (Lane, et al., 2016, p. 621). Forrester (1971) describes how the process of modelling is more important than the model itself. Drawing closer to the realities, we frequently talk about SD models operating as 'learning devices', in the style of Papert (1980). Which bring us to the paper by Stouten et al., because the need to consider learning in, shall we euphemistically say, 'a bit more detail', is nicely expressed in their observation - summarising Akkerman et al. (2007) - that:

"... just putting two or more individuals in the same room and assigning them the same task is not a guarantee for true collaboration. For collaboration, group members must actively communicate and interact with each other with the intention of establishing a common focus and achieving a common goal." (Stouten, et al., 2017a, p. TBC)

Stouten et al. build on this insightful remark by providing experimental data on the problem of how one goes about helping people to extract something useful from modelling. It is sound work that contributes to this 'social' side of the SD research agenda. In this Discussant piece I want to look again at this area of research, this interest in the social, in human behaviour, and the sometime harnessing of this interest to experiments and data collection. The reason for this is that this area of work relates strongly to a new 'turn' in Operational Research thinking, a turn that is called 'Behavioural OR'. In this piece I want to discuss briefly what Behavioural OR is and make an argument for a 'Behavioural SD'. I want to offer some thoughts on what Behavioural SD might look like and how adopting a Behavioural SD perspective can draw together a range of seemingly disparate but actually affine areas of work in an illuminating way. I shall end with a note of caution but nevertheless suggest that Behavioural SD - 'BehSD' - could prove to be a constructive way forward. 


\section{The 'Behavioural Turn' in OR}

Regrettably in my view, the Behavioral Turn in OR has become known as 'BOR'. It has attracted considerable interest in frequent years. From a UK perspective, from 2013 the OR Society created a series of 'Fostering Behavioural Operational Research' workshops to explore the area - before rapidly deciding that interest had gathered momentum with or without the Society's involvement. There are now BOR streams at UK, European, North American and international conferences, a special issue of the European Journal of Operational Research has appeared (Franco \& Hämäläinen, 2016b) and a collection of pieces that emerged from the OR Society initiative (Kunc, et al., 2016). Despite its unfortunate name, BOR is anything but boring. What, then, is this boisterous new kid in town, boldly striding into the centre of OR thinking?

The idea of studying the 'behavioural' aspects of what people do emerges from Decision Theory (Tversky \& Kahneman, 1974, 1981; Einhorn \& Hogarth, 1981). Briefly put, research consistently found that not only do people not always do what we might expect of them, they do not do what logic and rationality dictate. In more technical terms, there are differences between the descriptive accounts of human behaviour and the normative evaluations of what they might best do. These are seen in laboratory or natural experiments, for example involving situations in which people are asked to make a decision and are consistently observed to choose a different way if the same situation is presented differently. However, what people do is not capricious, not without structure. On the contrary, in psychological terms people's behaviour is both patterned and explicable. For example, it can be shown that when making decisions people use mental short-cuts or heuristics that work very well in many situations, that may be efficient in that they save time, or may intuitively speak to values and emotions. More broadly, people may exhibit behaviour which may be judged by observers as sub-optimal but which is highly meaningful to them - an almost ethnomethodological way of making sense of behaviour (Garfinkel, 1967). The 'Behavioural Turn' therefore aims to understand the gap between descriptive assessments of what people do and normative evaluations of what they should do.

The interest in problems with decision-making and the 'cognitive biases' that people exhibit is seen in the general management literature (Hammond, et al., 1998). However, from the outline above there is a broader terrain to consider. Indeed, the study of 'behavioural aspects', or the adoption of a 'behavioural perspective' has now extended considerably from its Decision Theory roots into a range of disciplines and been applied to many phenomena:

“...behavioral issues in decision making have been widely studied at the individual-, group-, and organizational levels by researchers in judgment and decision making, cognitive psychology, organization theory, game theory and economics" (Hämäläinen, et al., 2013, p. 632).

The application to OR follows rapidly. As a field interested in practical problem solving, the vagaries of human behaviour are clearly a concern. The OR interest may be quite focussed, for example; "studies consistently demonstrate that human decision-makers perform very differently to the rational-optimising decision-makers assumed in mathematical algorithms" (Robinson, et al., 2017, p. 253). Alternatively, BOR can be seen to cast its net into many aspects of the process of problem solving. In the same way, the Behavioural Turn began being applied to operations management (Croson \& Donohue., 2006; Bendoly, et al., 2006; Gino \& Pisano, 2008; Katsikopoulos \& Gigerenzer, 2013). 
I will discuss the behavioural perspective in more detail in the following sections, where I will be in a position to relate it to the specific interests of SD. I take this approach to offer to the System Science community (the journal's main readership) a tangible account of the application of a behavioural perspective. Nevertheless, the links with SD are, at one level, already clear. As implied by the Introduction, any research approach that tries to understand the various ways in which people interact with models and derive something from them will map easily into the research interests of SD. However, the BOR way of thinking has also been applied in a more tailored way to SD.

The key paper that explicitly introduced the behavioural way of thinking to SD is Hämäläinen et al. (2013). That work shows that varying the cues people are given and the nature of the questions they are asked, causes variations in people's ability to understand a problem involving flows of shoppers moving into and out of a fictional shop. This is an interesting piece in itself. But it is also interesting because of what it tells us about BOR. The paper offers new empirical evidence which addresses a specific research hypothesis. It addresses an interesting question and illuminates it powerfully using 'Behavioural ideas'. However, the area in which it operates - the idea that most people have difficulty understanding the trajectory ${ }^{2}$ over time produced by systems which involve accumulation into and/or out of a state variable, or stock - is by no means new. As the authors acknowledge, as an explicit area of research it is more than a decade old. Indeed, the idea in itself is at the very centre of SD, in that the field exists because feedback systems - which implies systems with stocks, since all feedback loops must contain a stock (Forrester, 1968a; 1968b) - are known to behave in counterintuitive ways, this being the raison d'être of SD (Forrester, 1970). Nevertheless, Hämäläinen et al. contributes new information and new insights and is very, very welcome. What I would like to suggest here is that that paper, and the Behavioural Turn more broadly, open up a very large terrain within which behavioural ideas might usefully be applied to SD.

The question I try to address in the next two sections is therefore: what is the scope of a behavioural approach to SD?

\section{A First Look At 'Behavioural System Dynamics'}

In this section I would like to try to offer some specific examples of how a behavioural perspective can illuminate the concerns of SD. Having analysed some specific points, in the following section I will broaden the discussions by offering a very tentative sketch map of the areas of the field of SD that can be illuminated using a behavioural approach, the phenomena that might be the subject of interest of BehSD.

One way - and it is only one way - of thinking about the Behavioural Turn is the notion of 'System 1 / System 2 '(Kahneman, 2011). The idea can be put simply as follows. People's minds do not work like computers and they behave in surprising, irrational ways; they depart from a rational and careful form of analysis, a type of thinking done using 'System 2'. However, their behaviour is not capricious or stupid. ${ }^{3}$ Instead, it can be understood as using 'System 1'. The main features of these two approaches are summarised in Table 1. It is, this approach suggests, not that humans are idiots who

\footnotetext{
2 In System Dynamics the term 'behaviour over time' is used as standard to refer to different values that a variable takes as time (or, in a model, simulated time) changes. To avoid confusion, in this piece I will instead use the term 'trajectory'.

${ }^{3}$ There is a link here with the ethnomethodological idea that people should not necessarily be dismissed as 'judgemental dopes' (Coulon, 1995) but rather seen as acting in ways which are meaningful to them, even though that meaning is subjectively (or inter-subjectively) rather than objectively established. The link between that concept and group model building in SD was identified by Lane (1999b; 2004)
} 
do not think at all. They may not use System 2 - but they do not fail to use a system. Rather, they use System 1. Using System 1 is an approach that works most of the time. Sometimes it reproduces the results of the 'correct' approach. Sometimes it has other advantages, generally expressed as 'If you meet a tiger in the jungle then you don't have time to try System 2'. But sometimes the differences in behaviour, actions and policies based on System 1 or System 2 matter greatly.

\begin{tabular}{|l|l|}
\hline \multicolumn{2}{|c|}{ Ways of Thinking About What To Do } \\
\hline System 1 & System 2 \\
\hline Fast & Slow \\
\hline Gut-feel \& intuition & Evaluation \& reasoning \\
\hline Automatic, unconscious & Consciously deliberative \\
\hline Short-cuts, heuristics & Sequential application of logic \\
\hline $\begin{array}{l}\text { Draws on past knowledge for } \\
\text { comparison and pattern-matching }\end{array}$ & $\begin{array}{l}\text { Willing to use effort and concentration } \\
\text { to study individual cases }\end{array}$ \\
\hline
\end{tabular}

Table 1: Two ways of describing human actions, in terms of their different types of thinking, known as 'System 1 / System 2'. Derived from Kahneman (2011).

The behaviours, actions, policies that result from using System 1 are not the same as those that result from using System 2 but the gap between them is not capricious but is itself systematic and explicable. 'Mistakes' are explicable and this framework helps with that explication. This can be illustrated using some examples from SD.

Since SD deals not with individual decisions but with policies (Forrester, 1960; 1961) the Decision Theory roots of the Behavioural Turn must be re-interpreted - and with caution. Using policy as a focus, archetypes offer a good place to start (Meadows, 1982; Senge, 1990). We might consider the lessons of 'Limits To Growth using the System 1 / System 2 idea (see Table 2, first row). This perspective then has three noteworthy features: the phenomenon is observable in experience and experiments; the System 1 perspective explains the phenomenon; and the System 2 perspective suggests a way to start improving things. These features repeat in the following.

After starting with archetypes, it becomes possible to broaden out, to consider four further phenomena that are of interest to system dynamicists, phenomena arising in different areas of life and at different levels of granularity.

That oscillations in supply chains are partly the result of human behaviour is a founding idea of SD (Forrester, 1958; 1992). The phenomenon has many aspects but work by Sterman (1989) indicates that one source is the failure of decision-makers to act as if most of their previous orders exist. In Table 2 a behavioural explanation is given in terms of System 1 and System 2.

The third example concerns our repeated inability to foresee the consequences of policies. The field has many examples but here we use that of the English child protection system, in which 'ripple effects' and damaging feedback loops resulted from policies which were implemented to have beneficial effect (Lane, et al., 2016). A behavioural account of this is shown in Table 2. This concentrates on the causal chain aspects of the phenomenon, and is well-supported in the broader 
literature (Axelrod, 1976; Dörner, 1990; Maddux \& Yuki, 2006). In fact. we know that our tendency to ignore non-linear relationships, and to imagine that relationships are directly functional rather than involving accumulation also play a role (Forrester, 1970). Indeed, the latter gives rise to arguably the most active 'pre-existing' areas of BehSD, the interest in the problems humans have understanding systems involving stocks (Sterman \& Booth Sweeney, 2007; Ritchie-Dunham \& Puente, 2008; Cronin, et al., 2009; Abdel-Hamid, et al., 2014; Stouten \& Groessler, 2017; Kapmeier, et al., 2017).

\begin{tabular}{|c|c|c|}
\hline $\begin{array}{c}\text { Observed } \\
\text { Phenomenon }\end{array}$ & System 1 & System 2 \\
\hline $\begin{array}{l}\text { Humans keep using a } \\
\text { policy that has ceased } \\
\text { to work } \\
\text { ('Limits To Growth') }\end{array}$ & $\begin{array}{l}\text { - A helpful compounding effect is } \\
\text { the only mechanism in play }\end{array}$ & $\begin{array}{l}\text { - There is a compounding effect } \\
\text { but previous success brings us up } \\
\text { against a limit }\end{array}$ \\
\hline $\begin{array}{l}\text { Humans make supply } \\
\text { chains oscillate }\end{array}$ & $\begin{array}{l}\text { - Keeping track of past orders is } \\
\text { hard and not a priority when } \\
\text { making re-order decisions under } \\
\text { time pressure }\end{array}$ & $\begin{array}{l}\text { - Past orders in supply line must be } \\
\text { taken into account when making } \\
\text { re-order decisions }\end{array}$ \\
\hline $\begin{array}{l}\text { Humans fail to } \\
\text { anticipate } \\
\text { consequences of } \\
\text { policies }\end{array}$ & $\begin{array}{l}\text { - Causal chains are short... } \\
\text { - and direct } \\
\text { - relationships are linear ... } \\
\text { - and instantaneous }\end{array}$ & $\begin{array}{l}\text { - Causal chain may be long ... } \\
\text { - and may involve feedback } \\
\text { - relationships may be non-linear } \\
\text { - } \text { and involve accumulation }\end{array}$ \\
\hline $\begin{array}{l}\text { Humans find it hard to } \\
\text { intuit behaviour of } \\
\text { complex dynamic } \\
\text { systems }\end{array}$ & $\begin{array}{l}\text { - My simple mental model is } \\
\text { complete and correct } \\
\text { - I can infer the consequences over } \\
\text { time of my mental model. }\end{array}$ & $\begin{array}{l}\text { - My mental model is worth } \\
\text { questioning and improving } \\
\text { - I need help rigorously deducing } \\
\text { the consequences of my mental } \\
\text { model. }\end{array}$ \\
\hline $\begin{array}{l}\text { Humans resist the use } \\
\text { of modelling for policy } \\
\text { analysis }\end{array}$ & $\begin{array}{l}\text { - A model that behaves strangely is } \\
\text { wrong and therefore useless } \\
\text { - Gut-feel is a sound guide to } \\
\text { action }\end{array}$ & $\begin{array}{l}\text { - Surprising behaviour is a chance } \\
\text { to learn, to improve intuition } \\
\text { - Modelling allow ideas to be } \\
\text { shared and understood and can } \\
\text { create commitment to action. }\end{array}$ \\
\hline
\end{tabular}

Table 2: Examples of phenomena of interest in SD, explicated using a 'Behavioural Turn' involving the System 1 / System 2 comparison.

The fourth example looks at that same failure of intuition when it comes to complex dynamic systems and considers the role of mental models (Doyle \& Ford, 1998; Lane, 1999a; Ritchie-Dunham \& Puente, 2008; Gary \& Wood, 2011). We can offer two ideas here: whether the set of ideas people use to form their intuition is up to the task and whether we are, in our heads, able to think through all of the consequences of those ideas. The diagnosis in terms of System 1 and System 2 is seen throughout the SD literature

The final example concerns the way people respond to the idea of doing SD modelling to support policy making. Rejection of puzzling model output, or even resistance to the need to do modelling at 
all, can be based on reasonable ideas - shown in the System 1 column. However, non-belief in models (c.f. Watt, 1977) can be countered: if there is deliberative engagement with the construction and trajectories of a model this can be useful (Forrester, 1960; Mass, 1991) - whilst effort spent on modelling in a team can produce many 'soft' benefits (Forrester, 1965; Richmond, 1997; Senge, 1990; Lane, 1992; Vennix, 1996; Rouwette, et al., 2011; Rouwette, 2011).

These five examples give a sense of what a Behavioural Turn applied to SD can offer. They also hint at the range of issues that might be illuminated. We take that idea further in the next section.

\section{A Tentative Map of the Behavioural SD Territory}

A Behavioural Turn applied to SD has the potential to illuminate many areas in the field. We can cast our net much wider than the oddities of particular decisions and across the whole realm of SD work. A behavioural perspective might be applied to a very wide range of phenomena: from the confusion people feel when a policy applied to a complex dynamic system has unexpected results (c.f. archetypes: Meadows, 1982; Senge, 1990); when deciding whether a model does or does not need to have a particular information link (c.f. bounded rationality Simon, 1982; Morecroft, 1985); when someone rejects the counter-intuitive behaviour of a model; when trying to learn about a system whilst operating as an actor within it (Sterman, 1994); or when a group or even an organisation find it difficult to absorb a model's lessons and do something different.

This is not a new idea in general terms:

"The purpose of behavioral studies is to make better use of OR models and to warn of the behavioral issues that need to be taken into account when using models to support decision making or making predictions" (Hämäläinen, et al., 2013, p. 624)

However, what we offer here is a first attempt to apply the Behavioural Turn to the granularity of the issues arising in SD. What is really only an initial view of where it might be applied is shown in Fig. 1. Here, a mind map illustrates just some of the phenomena to explore, phenomena arising as we use SD ideas of complex dynamic systems and apply them to the world of lived-in experience, ideas of mental models and their deficiencies and the different ways that formal modelling can be used.

The map returns us to the paper by Stouten et al. (2017b). We see that it has the same features as the examples in the previous section: it is a solid piece of experimental work; it can be interpreted as located in the Fig. 1 area on 'Working with Formal Models', relating to the idea that learning from models is a complex matter replete with behavioural issues; and the work does offer illumination on this topic. As the map proposes, there is a large space in which the same approach might be used and to great effect.

Fig. 1 (next page): A tentative map of 'Behavioural System Dynamics' - the issues and phenomena arising in the SD field that might be researched using a behavioural perspective. 


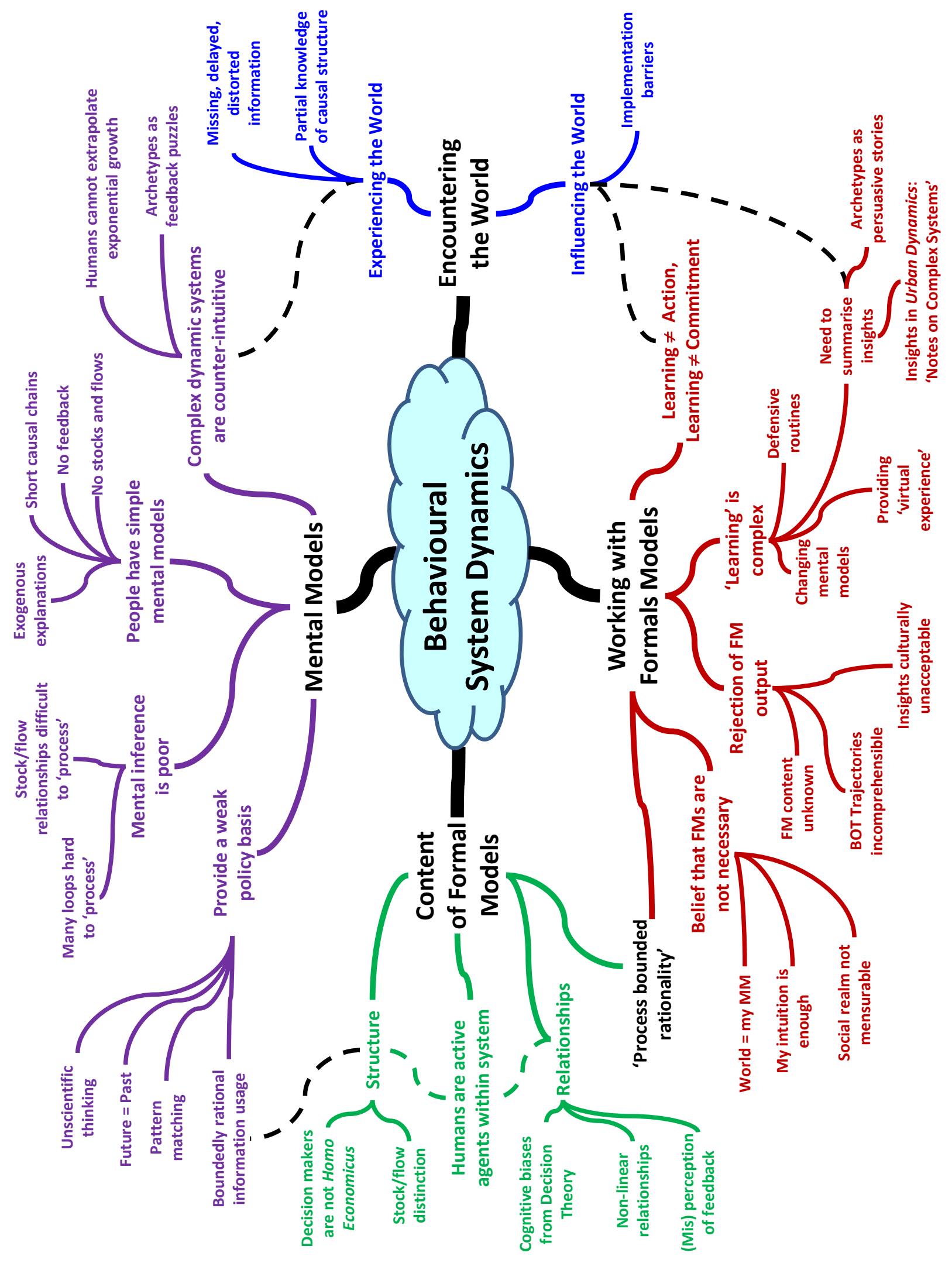




\section{'Behavioural System Dynamics': Warning - and Opportunity}

To close this piece I want briefly to discuss what BehSD must not be and what it could be.

On the first - warning - note, I recall a plenary session at the 2014 OR conference at Royal Holloway, University of London, a session that emerged from the OR Society's fostering of BOR. I was one of a group that made brief presentations on the Behavioural Turn and how it might be useful in many areas and this was followed by a panel discussion. To say that the session 'fell dead-born from the press' certainly, via its Humean comparison, over-praises the value of the event and, perhaps, unkindly overstates the reaction. Nevertheless - and I must certainly acknowledge my part in this the reception was very muted. The audience did not seem impressed or interested. Possibly it was that the ideas presented were too theoretical and abstruse; though there were 'practitioners' as well as 'academics' in the panel. Perhaps we just did a poor job. But I wonder whether, at that event, the idea of BOR did little more than re-state the obvious. Perhaps it is that after $30+$ years of Problem Structuring Methods (Rosenhead, 2009) that community was already well-attuned to the importance of 'process issues' in OR. Or perhaps, given, the claim that the Behavioural Turn speaks to the central concerns of OR - c.f. Franco \& Hämäläinen's 'Returning to the roots of the OR profession' (2016a) - the audience already had a very sound understanding of those roots already, had never abandoned them in the first place and therefore needed no encouragement to 'return'. Forgive the note of scepticism. However, when it comes to the Behavioral Turn, I am not the first to notice that there are "members of the OR community who remain unconvinced" or to suggest that a gap between the interests of academics and practitioners may be a reason (Brocklesby, 2016, p. 796). My concern, which was initiated by this experience, is that BOR might look like little more than the large-scale application of a complex language and terminology to re-describe things already known. As such it reminds me of the criticism that certain styles of social theory have little of substance to say but nevertheless have a "... grim determination to blanket social reality with a vast conceptual quilt leaving nothing exposed ..." (van den Berg, 1998, p. 222, italics in original). Consequently, I can understand people asking 'Is there anything new here but a label?' What BOR must not be is just a re-labelling exercise. We must avoid this - and we can; by showing the opportunity that the Behavioural Turn offers.

To do so, we need clarity about what BehSD can be. It can look at the quirks and oddities of human behaviour not just when taking decisions, and not just as well-crafted archetypes that offer stories about odd feedback, but at all of the stages of encountering, thinking about, modelling and then doing something better to understand complex dynamic systems. The map offered here is a very first attempt to cast the net wide whilst also offering some granularity. Note that with all of the elements in this map we would demand three properties very similar to those described earlier: the phenomenon is observable in controlled or natural experiments; a behavioural perspective explains (or has the potential to explain) the phenomenon; and that explanation suggests a way to start improving things. With such an approach, BehSD can provide coherence and rigour across a broad research front, showing similarities in approach and findings to different researchers. In this way, BehSD can become a way of looking at the world that unearths new phenomena and that finds ways to address those phenomena, i.e. help people work through unhelpful behavioural effects. It can contribute to 'system improvement'. This is the opportunity: to show that BehSD is, indeed, the best ${ }^{4}$ way forward.

\footnotetext{
${ }^{4}$ Try saying 'BehSD'.
} 


\section{Acknowldgements}

Early versions of the ideas explored here were presented at and/or developed during the (UK) OR Society's 'Fostering Behavioural Operational Research' workshops in 2013 \& 2014 and at the EuSDW-VII workshop on Bergen in 2015. I am grateful to the participants of all of these events - but shoulder the blame for any errors myself.

\section{References}

Abdel-Hamid, T., Ankel, F., Battle-Fisher, M., et al. (2014). Public and health professionals' misconceptions about the dynamics of body weight gain/loss. System Dynamics Review, 30, 58-74.

Akkerman, S., Van den Bossche, P., Admiraal, W., et al. (2007). Reconsidering group cognition: From conceptual confusion to a boundary area between cognitive and socio-cultural perspectives? Educational Research Review, 2, 39-63.

Axelrod, R. (1976) Structure of Decision: The cognitive maps of political elites. Princeton: Princeton University Press.

Bendoly, E., Donohue, K. \& Schultz, K. (2006). Behavior in operations management: Assessing recent findings and revisiting old assumptions. Journal of Operations Management, 24, 737-752.

Brecht, B. (2006) Life of Galileo / Leben des Galilei (trans. J. Willet). London: Methuen Drama.

Brocklesby, J. (2016). The what, the why and the how of behavioural operational research: An invitation to potential sceptics. European Journal of Operational Research, 249, 796-805.

Checkland, P. B. (1981) Systems Thinking, Systems Practice. Chichester: Wiley.

Coulon, A. (1995) Ethnomethodology. London: Sage.

Cronin, M. A., Gonzalez, C. \& Sterman, J. D. (2009). Why don't well-educated adults understand accumulation? A challenge to researchers, educators, and citizens. Organizational Behavior and Human Decision Processes., 108, 116-130.

Croson, R. \& Donohue., K. (2006). Behavioral causes of the bullwhip and the observed value of inventory information. Management Science, 52, 323-336.

Dörner, D. (1990). The Logic of Failure. Philosophical Transactions of the Royal Society of London. Series B, Biological Sciences, 327, 463-473.

Doyle, J. K. \& Ford, D. N. (1998). Mental Models Concepts for System Dynamics Research. System Dynamics Review, 14, 3-29.

Eden, C. (1992). Strategy development as a social process. Journal of Management Studies, 29,

Einhorn, H. J. \& Hogarth, R. M. (1981). Behavioural Decision Theory: Process of judgement and choice. Annual Review of Psychology, 32, 53-88.

Emery, F. E. \& Trist, E. L. (1969) Socio-technical Systems (re-print of 1960 original). In: Ed. Emery, FE Systems Thinking: Selected readings. Harmondsworth: Penguin, 281-296.

Forrester, J. W. (1958). Industrial Dynamics: A major breakthrough for decision makers. Harvard Business Review, 36, 37-66.

Forrester, J. W. (1960) The Impact of Feedback Control Concepts on the Management Sciences. In: Collected Papers of Jay W. Forrester (1975 collection). Cambridge, MA: Wright-Allen Press, 45-60.

Forrester, J. W. (1961) Industrial Dynamics. Cambridge, MA: MIT Press.

Forrester, J. W. (1965). A New Corporate Design. Industrial Management Review (now the Sloan Management Review), 7, 5-17.

Forrester, J. W. (1968a). Market growth as influenced by capital investment. Industrial Management Review (now the Sloan Management Review), 9, 83-105.

Forrester, J. W. (1968b) Principles of Systems. Cambridge, MA: MIT Press.

Forrester, J. W. (1970) Counterintuitive behaviour of social systems. In: Collected Papers of Jay W. Forrester (1975 collection). Cambridge, MA: Wright-Allen Press, 211-244. 
Forrester, J. W. (1971). "The" model versus a modelling "process" (republished 1985). Dept. memo D1621-1, system dynamics group, MIT, republished in System Dynamics Review, 1, 133-134.

Forrester, J. W. (1992) From the Ranch to System Dynamics. In: Ed. Bedeian, AG Management Laureates: A collection of autobiographical essays (vol. 1). Greenwich CT: JAI Press, 335-370.

Forrester, J. W. \& Senge, P. M. (1980) Tests for Building Confidence in System Dynamics Models. In: Eds. Lagasto, AA, Forrester, JW and Lyneis, JM System Dynamics: TIMS Studies in the Management Sciences. Oxford: North-Holland, 209-228.

Franco, L. A. \& Hämäläinen, R. P. (2016a). Editorial - Behavioural operational research: Returning to the roots of the OR profession. European Journal of Operational Research, 249, 791-795.

Franco, L. A. \& Hämäläinen, R. P. (eds.). (2016b) Behavioural Operational Research (Feature cluster in European Journal of Operational Research 2493 ).

Garfinkel, H. (1967) Studies in Ethnomethodology. Englewood Cliffs, NJ: Prentice Hall.

Gary, M. S. \& Wood, R. E. (2011). Mental models, decision rules, and performance heterogeneity. Strategic Management Journal, 32, 569-594.

Gass, S. I. (1983). Decision-aiding models: validation, assessment, and related issues for policy analysis. Operations Research, 31, 603-631.

Gino, F. \& Pisano, G. (2008). Towards a Theory of Behavioural Operations. Manufacturing and Service Operations Management, 10, 676-691.

Hämäläinen, R. P., Luoma, J. \& Saarinen, E. (2013). On the importance of behavioral operational research: The case of understanding and communicating about dynamic systems. European Journal of Operational Research, 228, 623-634.

Hammond, J. S., Keeney, R. L. \& Raiffa, H. (1998). The Hidden Traps In Decision Making. Harvard Business Review, 76, 47-58.

Kahneman, D. (2011) Thinking, Fast And Slow. London: Penguin.

Kapmeier, F., Happach, R. M. \& Tilebein, M. (2017). Bathtub Dynamics Revisited: An Examination of Déformation Professionelle in Higher Education. Systems Research and Behavioral Science, 34, 227-249.

Katsikopoulos, K. V. \& Gigerenzer, G. (2013). Behavioral operations management: a blind spot and a research program. Journal of Supply Chain Management, 49, 3-7.

Kunc, M., Malpass, J. \& White, L. (eds.). (2016) Behavioral Operational Research: Theory, Methodology and Practice. London: Palgrave Macmillan UK.

Lane, D. C. (1992). Modelling As Learning: A consultancy methodology for enhancing learning in management teams. European Journal of Operational Research, 59, 64-84.

Lane, D. C. (1999a). Friendly Amendment: A commentary on Doyle and Ford's proposed re-definition of 'mental model'. System Dynamics Review, 15, 185-194.

Lane, D. C. (1999b). Social Theory and System Dynamics Practice. European Journal of Operational Research, 113, 501-527.

Lane, D. C. (2004). Irrational Agents or Accomplished Social Actors? Systems Research and Behavioral Science, 21, 433-438.

Lane, D. C. (2006). It Works In Practice But Does It Work In Theory? Comment on the paper by Vriens and Achterbergh. Systems Research and Behavioral Science, 23, 565-570.

Lane, D. C. (2010). Participative Modelling and Big Issues: Defining features of system dynamics? Systems Research and Behavioral Science, 27, 461-465.

Lane, D. C., Munro, E. \& Husemann, E. (2016). Blending systems thinking approaches for organisational analysis: reviewing child protection in England. European Journal of Operational Research, 251, 613-623.

Maddux, W. \& Yuki, M. (2006). The "ripple effect": cultural differences in perceptions of the consequences of events. Personality and Social Psychology Bulletin, 32, 669-683.

Mass, N. J. (1991). Diagnosing surprise model behavior: a tool for evolving behavioral and policy insights (1981). System Dynamics Review, 7, 68-86. 
Meadows, D. H. (1982). Whole earth models and systems. The Coevolution Quarterly, Summer, 98108.

Miser, H. (2001) Practice of operations research and management science. In: Eds. Gass, SI and Harris, CM Encyclopedia of Operations Research and Management Science. New York: Springer, 625-630.

Morecroft, J. D. W. (1985). Rationality in the analysis of behavioral simulation models. Management Science, 31, 900-916.

Papert, S. (1980) Mindstorms: Children, computers and powerful ideas. Brighton, UK: Harvester Press Ltd.

Phillips, L. D. (1984). A Theory of Requisite Decision Models. Acta Psychologica, 56, 29-48.

Rahmandad, H., Oliva, R. \& Osgood, N. D. (eds.). (2015) Analytical Methods for Dynamic Modelers. Cambridge MA: MIT Press.

Richmond, B. (1997). The Strategic Forum: Aligning objectives, strategy and process (originally published 1987). System Dynamics Review, 13, 131-148.

Ritchie-Dunham, J. L. \& Puente, L. M. (2008). Strategic clarity: Actions for identifying and correcting gaps in mental models. Long Range Planning, 41, 509-529.

Roberts, E. B. (2007). Making System Dynamics Useful: A personal memoir. System Dynamics Review, 22, 119-136.

Robinson, S., Dimitriou, S. \& Kotiadis, K. (2017). Addressing the sample size problem in behavioural operational research: simulating the newsvendor problem. Journal of the Operational Research Society, 68, 253-268.

Rosenhead, J. (2009). Reflections on Fifty Years of Operational Research. Journal of the Operational Research Society, 60, s5-s15.

Rouwette, E. A. J. A. (2011). Facilitated modelling in strategy development: measuring the impact on communication, consensus and commitment. The Journal of the Operational Research Society, 62, 879-887.

Rouwette, E. A. J. A., Korzilius, H., Vennix, J. A. M., et al. (2011). Modeling as Persuasion: The impact of group model building on attitudes and behaviour. System Dynamics Review, 27, 1-21.

Senge, P. M. (1990) The Fifth Discipline: The art and practice of the learning organization. New York: Doubleday/Currency.

Simon, H. A. (1982) Models of Bounded Rationality. Cambridge, MA: MIT Press.

Sterman, J. D. (1989). Modelling managerial behaviour: misperceptions of feedback in a dynamic decision making experiment. Management Science, 35, 321-339.

Sterman, J. D. (1994). Learning In And About Complex Systems. System Dynamics Review, 10, $291-$ 330.

Sterman, J. D. \& Booth Sweeney, L. (2007). Understanding Public Complacency About climate Change: adults' mental models of climate change violate conservation of matter. Climatic Change, 80, 213-238.

Stouten, H. \& Groessler, A. (2017). Task Complexity in Individual Stock Control Tasks for Laboratory Experiments on Human Understanding of Dynamic Systems. Systems Research and Behavioral Science, 34, 62-77.

Stouten, H., Polet, H., Heene, A., et al. (2017a). Learning from collaboratively playing with simulation models in policy making: An experimental evaluation in fisheries management. Systems Research and Behavioral Science, 34, TBC.

Stouten, H., Polet, H., Heene, A., et al. (2017b). Learning from collaboratively playing with simulation models in policy making: An experimental evaluation in fisheries management. Systems Research and Behavioral Science, 34, 404-414.

Tinker, A. \& Lowe, A. (1984). One-Dimensional Management Science: The making of a technocratic consciousness. Interfaces, 14, 40-49.

Trist, E. L. \& Bamforth, K. W. (1951). Some Social and Psychological Consequences of the Longwall Method of Coal-Getting: An Examination of the Psychological Situation and Defences of a 
Work Group in Relation to the Social Structure and Technological Content of the Work System. Human Relations, 4, 3-38.

Tversky, A. \& Kahneman, D. (1974). Judgment under uncertainty: heuristics and bias. Science, 185, 1124-1131.

Tversky, A. \& Kahneman, D. (1981). The Framing of Decisions and the Psychology of Choice. Science, 211, 453-458.

van den Berg, A. (1998) Is Sociological Theory Too Grand For Social Mechanisms? In: Eds. Hedström, $\mathrm{P}$ and Swedberg, R Social Mechanisms: An analytical approach to social theory. Cambridge: CUP, 204-237.

Vennix, J. A. M. (1996) Group Model-building: Facilitating team learning using system dynamics. Chichester: Wiley.

Watt, K. E. F. (1977). Why won't anyone believe us? Simulation, 28, 1-3.

Weil, H. B. (2007). Application of System Dynamics to Corporate Strategy: An evolution of issues and frameworks. System Dynamics Review, 22, 137-156. 